\title{
A Lama da Samarco e o Crime Corporativo: uma reflexão necessária
}

The Samarco Mud and Corporate Crime: a necessary reflection

El Lama del Samarco y el Crimen Corporativo: una reflexión necesaria

Carolina Machado Saraiva Doutorado pela Universidade Federal de Minas Gerais, Profa. Adjunta Universidade Federal de Ouro Preto http://lattes.cnpq.br/0712097340474477 https://orcid.org/0000-0002-0846-1528 carolamsaraiva@gmail.com

Pamella Thaís Magalhães Ferreira Mestranda em Administração pela Universidade Federal de Lavras (UFLA). http://lattes.cnpq.br/8618345443467546 https://orcid.org/0000-0003-4436-1687

pamella.magalhaes0@gmail.com

Resumo: O presente artigo refere-se a um ensaio teórico que objetiva contribuir com os estudos críticos organizacionais ao lançar luzes sobre o tema de crime corporativo. Comumente, as organizações são exploradas considerando seus aspectos positivos, tratando o seu lado sombrio como algo excepcional, acabando por favorecer a ocorrência dos crimes corporativos. Tendo isso posto, busca-se lançar reflexões acerca do evento ocorrido no dia cinco de novembro de 2015 no município de Mariana (MG), conhecido como "Lama da Samarco" e a teoria sobre crimes corporativos, uma vez que esse evento teve como consequências a morte de dezenove pessoas, famílias desabrigadas, prejuízos econômicos, problemas ambientais e cálculo de atingidos inestimáveis. As conclusões apontam para aproximações e similaridades entre o evento da "Lama da Samarco" e a teoria sobre crimes corporativos, porém, defende-se a necessidade de tais reflexões como forma de observar práticas sombrias das organizações, desencadear o pensamento crítico e promover práticas transformadoras. Diante da atualidade desse acontecimento, busca-se evidenciar a adoção de tais práticas presentes na sociedade, revendo o viés de que pesquisas que abordem os aspectos negativos do management recebem pouco espaço acadêmico.

Palavras Chave: Crime Corporativo; Lama da Samarco; Lado Sombrio.
Abstract: This article refers to a theoretical essay that aims to contribute to critical organizational studies by shedding light on the subject of corporate crime. Organizations are often exploited in their positive aspects, treating their dark side as exceptional, and this ultimately favors the occurrence of corporate crimes. With this in mind, we seek to reflect on the event that occurred on November 5, 2015, in the municipality of Mariana (MG), known as the "Lama da Samarco", and the theory of corporate crimes, since this event caused death of nineteen people, in homeless families, economic losses, environmental consequences, and calculation of inestimable victims. The conclusions point to approximations and similarities between the "Samarco's Lama" event and the theory of corporate crimes, but the need for such reflections is defended as a way to observe shady practices of organizations, trigger critical thinking and promote transformative practices. Given the current relevance of this event, we seek to highlight the adoption of such practices present in society, reviewing the bias that research that addresses the negative aspects of management receive little academic space.

Keywords: Corporate Crime; Mud Samarco; Dark side.
Resumen: El presente artículo se refiere a un ensayo teórico que objetiva contribuir con los estudios críticos organizacionales al lanzar luces sobre el tema del crimen corporativo. Comúnmente, las organizaciones son explotadas considerando sus aspectos positivos, tratando su lado sombrío como algo excepcional, acabando por favorecer la ocurrencia de los crímenes corporativos. En este sentido, se busca lanzar reflexiones sobre el acontecimiento ocurrido el día 5 de noviembre de 2015 en el municipio de Mariana (MG), conocido como "Lama de Samarco" y la teoría sobre crímenes corporativos, ya que ese evento tuvo como consecuencias la muerte de diecinueve personas, familias desamparadas, pérdidas económicas, problemas ambientales y cálculo de alcances inestimables. Las conclusiones apuntan a aproximaciones y semejanzas entre el evento de la "Lama de Samarco" y la teoría sobre crímenes corporativos, sin embargo, se defiende la necesidad de tales reflexiones como forma de observar prácticas sombrías de las organizaciones, desencadenar el pensamiento crítico y promover prácticas transformadoras Ante la actualidad de este acontecimiento, se busca evidenciar la adopción de tales prácticas presentes en la sociedad, revisando el sesgo de que investigaciones que aborden los aspectos negativos del management reciben poco espacio académico.

Palabras clave: Crimen Corporativo; Lama de Samarco; Lado sombrío.

\section{A Lama da Samarco: o terror inicial}

A barragem de Fundão, pertencente à empresa Samarco, rompeu-se em Mariana - MG, na tarde do dia cinco de novembro de dois mil e quinze. Esse rompimento ocasionou o lançamento de 62 milhões de metros cúbicos de lama ao meio ambiente, o que equivale a mais de 20 mil piscinas olímpicas contendo rejeitos da mineração (Ceraque \& Mena, 2015). Além disso, a lama foi responsável por cobrir todo o distrito de Bento Rodrigues e deixá-lo em condições inviáveis para habitação, chegando a afetar também as regiões de Águas Claras, Ponte do Gama, Paracatu, Pedras e as cidades de Barra Longa e Rio Doce. Os rejeitos da barragem também chegaram a atingir cidades da Região Leste do estado de
Minas Gerais e o Espírito Santo (G1, 2015c). O distrito de Bento Rodrigues foi o mais atingido, onde a lama chegou a uma altura de 15 metros, cobrindo telhados, arrastando carros e caminhões, deixando pessoas soterradas e ilhadas (Parreiras, 2016). Depois disso, além da região de Bento Rodrigues ter se tornado um lugar de impossível habitação (Carneiro, 2016), o rompimento foi responsável pela morte de dezenove pessoas, dentre elas, trabalhadores da mineradora e moradores das regiões afetadas e mais de 1.200 pessoas desabrigadas (G1, 2015d). Os desabrigados foram realocados em hotéis e pousadas e hoje residem em casas alugadas pela mineradora (Samarco, 2015). 
De acordo com o relatório de "Avaliação dos efeitos e desdobramentos do rompimento da Barragem de Fundão em Mariana-MG", disponibilizado pela Secretaria de Estado de Desenvolvimento Regional, Política Urbana e Gestão Metropolitana, o evento do rompimento da barragem trouxe conseqüências tanto microrregionais, quanto macrorregionais com danos ambientais, humanos, bem como danos à saúde e segurança pública, impactos sobre a cultura, educação e lazer, danos à organização social e também danos materiais (Governo do Estado de Minas Gerais, 2016).

Outrossim, em um relatório inicial publicado pelo Instituto Brasileiro do Meio Ambiente e dos Recursos Naturais Renováveis (IBAMA), no dia vinte e seis de novembro de dois mil e quinze, o episódio teve classificação de "Desastre Nível IV", que são os "desastres de muito grande porte". A lama foi responsável por soterrar as nascentes do Rio Doce e pela mortalidade de sua fauna. Seguindo o curso do Rio Doce, os rejeitos foram levados até a foz do Oceano Atlântico, chegando ao município de Linhares - ES, totalizando em $663,3 \mathrm{~km}$ de corpos hídricos diretamente impactados. Todos os municípios que dependem da água dos rios afetados foram prejudicados em seu abastecimento para 0 consumo humano, dessedentação de animais e irrigação da lavoura. Além disso, as atividades pesqueiras, que eram utilizadas como forma de subsistência por muitos, foram inviabilizadas e as atividades turísticas das regiões que as ofereciam, também foram prejudicadas.

Destituídas de suas formas de subsistência de produção rural pela destruição de lavouras e pastos, ou da prestação de serviços relativos ao turismo à região, as populações restaram sem alternativa para seu próprio sustento e sem perspectiva de retomada de suas vidas a curto prazo. A separação física dos vizinhos e grupos de uma comunidade faz com que as pessoas percam suas identidades e referências tradicionais, culturais, religiosas e de lugar, trazendo transtornos aos seus valores intrínsecos e intangíveis, que não são sanados com a distribuição de kits, propostas de indenizações ou o aluguel de casas em outros bairros (IBAMA, 2015, p. 28).

Professores e alunos da Universidade Federal do Espírito Santo pesquisam sobre o efeito da lama no mar de Regência e na foz do Rio Doce. Em um relatório, onde são apresentados resultados parciais de amostras coletadas na plataforma continental adjacente ao Rio Doce, é destacado que parte dessa lama proveniente do rompimento da barragem da Samarco está se assentando no fundo do mar e na foz do rio, o que desencadeia mudanças prejudiciais na vida aquática e marinha. Foram coletadas amostras em 15 estações diferentes e, uma análise de fração total da água, incluindo o material particulado em suspensão, mostrou um aumento nos níveis de alumínio, ferro, manganês e cromo na desembocadura do Rio Doce. Além disso, as análises qualitativas feitas pelo grupo de pesquisadores indicam uma redução no número de espécies marinhas em relação ao esperado. Foi observada também, alteração no ecossistema na desembocadura do Rio Doce, com substituição de espécies, redução da biodiversidade e da abundância de espécies, levando a futuros problemas em volumes pesqueiros da região (Universidade Federal do Espírito Santo, 2016).

A Samarco declarou que faz análises diárias no conteúdo da água em 34 pontos diferentes no oceano e que os resultados dessas análises indicam que o conteúdo da água está dentro das resoluções do CONAMA (Conselho Nacional de Meio Ambiente). Há uma preocupação do Comitê Interfederativo, criado para supervisionar as ações da Samarco, de como a empresa irá posicionar suas ações de contenção do despejo de rejeitos na bacia do Rio Doce, uma vez que, inicia-se em outubro o período chuvoso. Entretanto, os pesquisadores da UFES, alertam que valores de ferro mesmo abaixo do estabelecido pelo CONAMA, não são suficientes para indicar ausência de impactos passíveis de serem gerados, pois, pode haver rápida assimilação de ferro pelo fitoplâncton, tendo a possibilidade de gerar ferro dissolvido, o que ocasiona na diminuição de valor de ferro na fração. Ou seja, os valores de ferro abaixo do esperado, podem ser resultantes da rápida absorção pelo conjunto de organismos plânctons, devolvendo o ferro de forma dissolvida na água, gerando um índice abaixo do estipulado (Universidade Federal do Espírito Santo, 2016).

As condições após o rompimento não são superáveis e nem suportáveis pelas comunidades nem elas estando preparadas, informadas e mobilizáveis sem receber ajuda externa da área afetada como ocorreram neste caso. Segundo o laudo inicial publicado pelo IBAMA (2015), a condição de normalidade da área depende da ação das três esferas governamentais: municipal, estadual e federal. Além disso, "o rompimento da barragem de fundão causou a destruição de 1.469 hectares ao longo de $77 \mathrm{~km}$ de cursos d'água, incluindo áreas de preservação permanente" ( IBAMA, 2015) e, qualquer exploração econômica direta em quaisquer faixas marginais de cursos d'água em zonas rurais ou urbanas não é mais permitida. Entre os danos causados foram citados: mortes de trabalhadores; desalojamento de populações; destruição de estruturas públicas e privadas; interrupção no abastecimento de água; interrupção da pesca por tempo indeterminado; interrupção do turismo; mortalidade da biodiversidade e fauna terrestre; assoreamento de curso d'água; alterações dos padrões da qualidade de água doce, salgada e salobra, sensação de perigo e desamparo da população entre outros fatores. A mensuração dos atingidos é impossibilitada em vista dos danos causados pelos rejeitos da lama, pela grande devastação provocada e pelo percurso corrido por ela.

\subsection{A Responsabilização}

De acordo com o Promotor de Justiça da Comarca de Mariana, Guilherme Meneghin, a falha principal entre várias outras que ocorreram, foi à ausência de uma sirene, ou qualquer aviso sonoro que pudesse alertar os moradores das regiões afetadas sobre 0 rompimento da barragem (Lampião, 2016). O aviso sonoro era uma medida que deveria constar no plano de emergência da empresa e era desconhecido pela Prefeitura Municipal de Mariana, pelo Departamento Nacional de Produção Mineral (DNPM) e também pelo governo do Estado de Minas Gerais. A empresa ainda obteve licença ambiental sem o aval do Ministério Público e recebeu dez 
medidas de reparo no Complexo de Germano ${ }^{1}$ como recomendação e se envolveu em um processo por impedir a fiscalização minerária.

PoEMAS, (2015) deixa claro que a barragem de Fundão era relativamente nova, tendo começado suas operações em 2008, devido à barragem de Germano ter chegado ao seu limite de contenção de rejeitos. Dessa maneira, uma barragem nova, deveria existir para receber o material que antes era despejado em Germano. Germano foi fechado e durante o processo de fechamento iniciou o de licenciamento para Fundão. Estudos de Impactos Ambientais e Relatório de Impactos Ambientais (EIARIMA) foram realizados e analisados pela Fundação Estadual do Meio Ambiente de Minas Gerais (FEAM-MG) em 2005 e, em 2008 - Conselho Estadual de Política Ambiental de Minas Gerais (COPAM) concedeu a licença de operação para Fundão.

A mineradora teve seu licenciamento renovado no ano de 2011, com validade até 2013 e, após esse vencimento, a empresa operou até 2015, ano do rompimento, sem nenhuma licença para continuar operando com a barragem de Fundão. O que houve em meio a esse processo de licenciamento foi, a empresa apresentar um novo EIA para aperfeiçoar a barragem de Fundão em 2012 e, em 2013 o ano do vencimento da licença, a Samarco entrou com um novo EIARIMA para unificar a barragem de Germano (que até então estava desativada) e Fundão, o que ocasionou no licenciamento para a unificação tanto em 2014, quanto em 2015 (PoEMAS, 2015).

Tendo isso posto, os autores inferiram que o rompimento da barragem de Fundão, adveio das obras de alteamento da barragem que se rompeu em junção com a barragem de Germano, logo, segundo eles, nos Estudos de Impactos Ambientais e no Relatório de Impactos Ambientais, deveriam estar previstos os riscos de rompimento da barragem durante a obra (PoEMAS, 2015). Ressalta-se ainda, que a utilização do córrego de Brumado poderia ter sido utilizada como alternativa ao córrego de Fundão, onde a barragem foi construída, mas mesmo conhecendo os riscos envolvidos, a Samarco optou por construir a barragem de Fundão (MPF, 2016).

Além disso, PoEMAS, 2015 considera que o processo de licenciamento, por ter sido fragmentado em diversos pedidos e concessões, se comportou como uma estratégia da empresa para subdimensionar os impactos gerados e a quantidade de atingidos, pois foi dimensionado de forma separada cada um desses impactos como especificidades de cada projeto ou cada obra. Analogamente, as audiências públicas que visavam discutir tais obras e levar esclarecimentos à população, não debatiam a atividade de exploração do minério como um todo, demonstrando seus impactos socioambientais e tampouco a sua área de influência. Essas audiências eram, assim como seus processos de licenciamento, fragmentadas, o que acaba por prejudicar o debate com a sociedade, dificultando o entendimento, acompanhamento e controle dos processos, deixando informações excessivas e de maneira generalizada.
De acordo com o documento emitido pelo Ministério Público Federal (MPF), onde constam as denúncias sofridas pela mineradora Samarco, suas controladoras e demais responsáveis pelo rompimento, a barragem de Fundão apresentava anomalias e estratégias para velar irregularidades desde a concepção de seu EIA. O documento do MPF ainda frisa que o vale do córrego de Fundão, onde foi criada a barragem, foi construído com a intenção de receber os rejeitos e lama advinda da Samarco, mas que posteriormente serviu de sustentação, "clandestinamente, por rejeitos dessa natureza advindos da atividade desenvolvida pela VALE, na Mina Alegria, segundo relatório de vistoria elaborado pelo DNPM após o rompimento" (MPF, 2016, p. 63).

Para Moreira e Santana (2016) os crimes ambientais em que a Samarco foi incorrida, especificamente o pagamento de suas multas, tem aporte jurídico para ser cobrado de seus acionistas e empresas controladoras, por elas:

serem solidariamente responsáveis pelos danos ambientais gerados pelo rompimento da barragem localizada na região central de Minas Gerais, vez que o controle empresarial, reforça-se, parece ser realizado pelos co-ventures (MOREIRA E SANTANA, 2016, $\mathrm{s} / \mathrm{p}$.).

Foram indiciados e tiveram expedidos os pedidos de prisão preventiva pela Polícia Civil sete pessoas dentre elas, trabalhadores da Samarco e a responsável pelos laudos técnicos. Entre os indiciados está Ricardo Vescovi, ex-presidente licenciado da Samarco e Samuel Santana Paes Lourdes, engenheiro licenciado da empresa VOGBR, responsável pela declaração de estabilidade da barragem de Fundão. (Agencia Minas, 2016). Os indiciados irão responder pelos crimes de homicídio qualificado pelo dolo eventual ${ }^{2}$, inundação, corrupção e poluição de água potável.

O Ministério Público Federal, pela Procuradoria da República nos estados de Minas Gerais e Espírito Santo, efetuaram denúncia pela prática de atos delituosos, em face da empresa Samarco, suas controladoras Vale e BHP por responsabilidade civil e mais 23 pessoas. Entre as denúncias realizadas, estão envolvidos crimes ambientais: crime de poluição qualificado; crimes contra fauna e flora; crimes contra o ordenamento urbano e patrimônio cultural; etc., e também crimes previstos no Código Penal Brasileiro: crime de inundação; crimes de homicídios; crimes de desabamento/desmoronamento; crimes de lesão corporal (MPF, 2016).

Sobre os crimes ambientais dispostos, também estão previstos na denúncia, os crimes contra a administração ambiental, pois, a empresa contou com apresentação de declaração de estabilidade falsa e enganosa e ainda omitiu informações no RAL, Relatório Anual de Lavra e nos Planos de Aproveitamento Econômico. Além dos crimes ambientais, as denúncias dos crimes de homicídio se qualificam: pela impossibilidade e dificuldade de defesa das vítimas, graças à inoperância de um plano de ação emergencial; qualificação por motivo torpe; qualificação por emprego de meio insidioso ou cruel, ou de que possa resultar perigo comum (MPF, 2016).

\footnotetext{
${ }^{2} \mathrm{O}$ dolo eventual é caracterizado quando o agente realiza uma conduta, estando ciente das consequências e ainda assim assume o risco e cometela.

${ }^{1}$ Complexo de Germano se refere ao local físico onde está localizada a barragem de Fundão, que se rompeu no dia 05 de novembro de 2015 
Ao contrário do perigo, o risco não é uma decisão pessoal daquele que o encara. Ao revés, aquele que corre o risco não apenas não o criou, como nada pôde fazer, sem perturbar a normalidade de sua própria vida, para evitar-lhe as consequências, pelo singelo mas perturbador fato de que as decisões, ações e providências relacionadas ao controle e gestão do risco e de suas consequências não estão sob seu domínio, mas sob o domínio e, pois, responsabilidade de outrem (MPF, 2016, p 60-61).

Ademais, o Ministério Público Federal de acordo com suas investigações, deixa claro que a mineradora promoveu situações de risco ao longo do tempo que acabaram por contribuir com a ocorrência do rompimento da barragem de Fundão e, abastardando, que a empresa tinha consciência de possivelmente vidas humanas serem atingidas caso ela se rompesse (MPF, 2016). Ressalta-se ainda que nos EIA realizados a comunidade de Bento Rodrigues não foi considerada como vizinha, o que era de se esperar para que fossem mitigados os devidos impactos socioambientais, mas a comunidade não foi considerada, não pela Samarco não ter ciência da condição de risco de Bento:

tentou-se tornar invisível toda a comunidade de Bento, mas, ao mesmo tempo, mostrou-se, numa das trapaças dos jogos de linguagem de quem tenta iludir, o "ato falho" de prever com particular precisão o cenário da tragédia (MPF, 2016, p.64).

É importante ressaltar ainda, que a barragem havia apresentando anormalidades no recebimento de rejeitos desde o ano de 2009 com a recuperação do "Dique I", até um sinal de ruptura dado no ano de 2014 e a construção de mecanismos para drenagem em 2015 (MPF, 2016). Ou seja, a empresa teve ciência ao longo dos anos sobre os riscos em que as operações da barragem incorriam, prova disso foi às medidas de reparo ao longo dos anos de suas operações.

Coutinho, Avzaradel e Farias (2016) se posicionam afirmando que há um tratamento diferenciado e cuidadoso com o caso da Samarco, tanto pela esfera jurídica, quanto pela esfera midiática. Segundo os autores, tendo em vista os danos causados pelo rompimento, as prisões já deveriam ter sido realizadas, mas não foram devido às fortes relações políticas da empresa. É evidenciado por eles ainda, o tratamento de forma branda das mídias ao disseminar informações de forma a desatar conexões entre os fatos, exemplo disso, é a denominação do fenômeno do rompimento como "acidente de Mariana".

O Ministério Público Federal firmou acordo preliminar com as empresas Vale, BHP e Samarco com o objetivo de definir iniciativas que contribuam para a celebração de um acordo final nas ações civis públicas já em andamento. José Adércio Leite Sampaio, coordenador da força-tarefa do MPF, disse é de interesse do MPF através desse acordo, estabelecer ordem consensual na solução dos conflitos, almejando a reparação dos danos causados e a participação dos atingidos para que suas vozes sejam ouvidas.

O acordo prevê o firmamento do Termo de Ajustamento de Conduta Final (TACF) até o dia 30de junho de 2017, a liberação de uma quantia de $\mathrm{R} \$ 2,2$ bilhões para financiamento dos Programas de Reparação Socioambiental e Socioeconômica decorrentes do rompimento da barragem, $\mathrm{R} \$ 200$ milhões para a reparação dos danos socioeconômicos e socioambientais na região do município de Barra Longa (MG), no processo de realização do diagnóstico socioeconômico dos atingidos, serão obrigatórias à consulta e participação dos mesmos, além de outras medidas que foram previstas (MPF, 2017).

\subsection{Casos Análogos}

O rompimento da barragem de Fundão, pertencente à empresa Samarco não foi o primeiro caso de crime corporativo com consequências sociais e ambientais ocorrido até hoje. Outros casos também sofreram grande repercussão como o caso da petrolífera inglesa British Petroleum (BP) pelo derramamento de petróleo no Golfo do México, o caso "Rodhia" pela exposição de toxinas em que submeteu seus trabalhadores e comunidades e o caso da mineradora canadense Barrick Gold.

A Rodhia, no início chamada de Clorogil (subsidiária da multinacional francesa PROGIL) empresa localizada em Cubatão, produzia pesticidas organoclorados denominados pentaclorofenol e pentaclorofenato de sódio, popularmente chamados de "pó-dachina". Anos depois, já representada no Brasil como Rodhia S.A. a unidade de Cubatão passou a produzir solventes clorados. Esses solventes eram substâncias utilizadas em extintores de incêndio, que posteriormente foi proibido, pois, formava produtos tóxicos e envenenamentos durante o combate ao incêndio, o solvente também era utilizado na fabricação do gás Freon que agredia e destruía a camada de ozônio (Associação de Combate aos Poluentes, 2012).

Essa unidade produtiva foi responsável por dispor sobre o solo ou ainda sobre enterrar no chão da fábrica em áreas externas cerca de 20 mil toneladas de resíduos tóxicos. A Rodhia ao assumir definitivamente a razão social da fábrica e se deparando com a falta de espaço dentro da unidade iniciou o descarte de seus rejeitos tóxicos de forma clandestina (Associação de Combate aos Poluentes, 2012).

Poucos anos depois surgem às primeiras denúncias sobre a intoxicação por parte de seus operários, houve até mesmo mortes entre eles devido a intoxicação aguda e, como agravante, em locais onde se encontravam os despejos clandestinos houve ocupação pela população de baixa renda em virtude da expansão imobiliária. Além disso, o Ministério Público de São Paulo investigou e confirmou a contaminação do solo, das águas superficiais e subterrâneas e também da cadeia alimentar da região de São Vicente. A empresa contaminou áreas de preservação de mananciais, rios que poderiam ser usados para abastecimentos futuros dos municípios da região e contaminou também o solo e lençóis freáticos de áreas que poderiam ser usadas para expansão econômica da região. A região ficou impossibilitada de se exercer atividades de agricultura, moradia, indústrias ou qualquer outra atividade devido à contaminação e, essa realidade é irrecuperável.

Em meio a escândalos recorrentes vários lixões químicos foram encontrados. A Rodhia tentou se desvincular das denúncias, alegando que não tinha conhecimento dos mesmos e que eles eram praticados desde a Clorogil. Posteriormente, foi descoberto que seus trabalhadores não eram expostos somente aos lixões químicos, mas, no próprio processo de trabalho eles eram submetidos ao contato com substâncias tóxicas e nocivas, o ambiente de trabalho estava completamente contaminado 
(Associação de Combate aos Poluentes, 2012). Do total de 150 trabalhadores, 149 foram contaminados e os diagnósticos circularam entre: esteatose hepática; lesão irreversível do fígado, alterações hepáticas, comprometimento de todos os órgãos abdominais; reação inflamatória toráxica e abdominal; diminuição da defesa imunológica pelo aumento do timo, do baço, do tecido linfático; ocorrências neurotóxicas. Os trabalhadores ainda sofreram pressões para se demitirem "voluntariamente", mudarem de unidade (sendo que em uma nova unidade, continuaram a ter contato com os elementos tóxicos) ou ainda a demissão sumária (Mello, 1995).

Diante dos processos de denúncias, de escândalos recorrentes, de ajuizamento de processos pela Rodhia contra os trabalhadores, de processos contra a empresa de não cumprimento de determinações judiciais e de acordos perante os trabalhadores, a Rodhia encontra-se interditada e fechada. Até hoje, mais de 50 anos depois do início das operações da Rodhia ainda existem vestígios de seu lixo químico e ações judiciais trabalhistas ainda não resolvidas.

Além do caso descrito anteriormente, no ano de 2010 uma explosão ocorrida na empresa British Petroleum (BP) foi responsável por lançar cerca de cinco milhões de barris de petróleo no Golfo do México. Após a explosão a empresa só conseguiu controlar o vazamento após o 87ํ dia, o que resultou em mais de $1.500 \mathrm{~km}$ de petróleo espalhado no litoral norte-americano. (GreenpeacE, 2015).

A explosão proporcionou a morte de 11 trabalhadores e a empresa assumiu a culpa de 11 acusações criminosas e condenada a pagar 20,8 bilhões de dólares em multas e mais de 14 bilhões foram gastos para mitigar os efeitos da explosão (Veja.com, 2016). Contudo, a empresa assumiu a culpa somente da metade do vazamento e no mês de setembro de 2014 a empresa foi multada por "grave negligência ao desastre" (Greenpeace, 2015).

No que tange aos prejuízos ambientais, dados divulgados em novembro de 2010 citam milhares de aves e dezenas de tartarugas marinhas afetadas. Pessoas contratadas pela BP e outros estaduais e federais calcularam cerca de 6.100 aves mortas, sendo que 2.200 foram visivelmente atingidas por óleo, mais de 600 tartarugas mortas, sendo que 18 estavam afetadas pelo petróleo, pelo menos 153 golfinhos mortos foram levados para o Golfo, sendo que 8 estavam machados de óleo cru. (O Globo, 2011).

É importante ressaltar também, o caso da mineradora Barrick Gold, a maior exploradora de ouro do mundo, é alvo de recorrentes denúncias que se referem à violação do meio ambiente. Em 2011, o Greenpeace divulgou um relatório, que denunciava a mineradora pelo comprometimento das geleiras argentinas e de parte do Chile (cerca de 70\%), localizadas em Valadero e Pascua Lama, diminuindo a superfície das mesmas e contaminando a água, o que impacta na disposição do recurso hídrico e alterações climáticas (Greenpeace, 2011). Os processos de exploração da Barrick elevaram também a quantidade de metais pesados na água como o chumbo, alumínio, mercúrio e arsênio. As amostras que foram retiradas da água demonstram que os limites exigidos pela lei foram excedidos (Correio do Brasil, 2011).
Uma lei aprovada em 2010, que foi rejeitada em 2008 por prejudicar o desenvolvimento econômico do país, definiu um orçamento mínimo para a preservação de geleiras e da área periglacial. A lei estabelece que ativididades de mineração, de hidrocarbonos, as grandes obras de infraestrutura e a utilização de substâncias químicas são proibidas em regiões onde ocorrem os processos de transformação de água em gelo (Tae, 2011), mas ainda assim a mineradora continuou suas operações.

Em 2016, a mineradora sofreu novas denúncias por vazamentos de cianeto, na usina de Valadero, na Argentina, esses vazamentos ocorreram nessa mesma usina, em dois momentos distintos, num intervalo inferior a ano (Brasil Mineral, 2016). Um dos vazamentos ocorreu por desajuste no encanamento e outro por falha no circuito de transporte. A empresa canadense alegou que o ultimo vazamento não ocasionou em prejuízos ao meio ambiente e à saúde por não haver contato com curso de água externo, todavia, o primeiro foi capaz de atingir 1.072 metros cúbicos de cianureto, havendo contaminação dos rios Potrerillos, Las Taguas e La Palca, localizados nas proximidades à mina de extração de ouro (Exame, 2016), o que acabou por prejudicar o abastecimento de água de Jáchal e a produção agrícola dos que dependiam dos rios (Fernandéz, 2015).

Pelo segundo vazamento, ocorrido em 2016, a mineradora sofreu denúncias do Ministério do Meio Ambiente e Desenvolvimento Sustentável, por descumprir o protocolo de emergência e comunicação, uma vez que, a empresa levou cerca de oito dias para comunicar as autoridades sobre o vazamento de cianeto que ocorreu sobre um campo de lixiviação e, mais uma vez a suspensão das atividades da empresa não foi consolidada, o que causou revolta na população que habita a área. (El País, 2016).

Por fim, em março deste ano, houve o terceiro vazamento, por rompimento de dutos e que ocasionou na interrupção de exploração da minha Barrick Gold. A empresa informou que não continham líquidos perigosos no derramamento e mesmo assim organizações ambientais pediram a suspensão de suas atividades, o que ficou definido até que o duto fosse recuperado (Diário de Pernambuco, 2017).

Diante de casos de crimes corporativos expostos e considerando também a motivação, as consequências materiais e imateriais provocadas pelo rompimento da barragem da Samarco lança-se reflexões acerca da lama liberada pela mineradora e seus impactos negativos em relação ao lado sombrio das organizações e o crime corporativo, uma vez que, seus desdobramentos negativos foram assaz experimentados por seus trabalhadores, pela comunidade local e também pela população em geral, sabendo ainda que o rompimento da barragem não atinge somente as pessoas que foram desalojadas e/ou perderam seus familiares, pois, sendo meio ambiente um bem coletivo, não depender diretamente da área afetada como meio de subsistência, não necessariamente implica em não ser um atingido, uma vez que, o bem coletivo é um direito comum a determinado grupo ou sociedade.

Destarte, a fim de contribuir com o tema de crime corporativo e com estudos críticos organizacionais, adota-se como objeto de 
estudo o acontecimento da queda da barragem de lama da Samarco, lançando reflexões sobre esse acontecimento juntamente com suas características comuns aos crimes corporativos.

\section{Crime corporativo: o lado sombrio das organizações.}

Os estudos sobre crimes organizacionais ou crimes corporativos apresentam perspectivas que alicerçam o tema, assaz diferentes. Em pesquisas realizadas nos sites "Scielo" e "Periódicos Capes" por referenciais recentes (últimos 05 anos) foram encontrados estudos que se diferem no tratamento dado ao tema. Estudiosos como Whyte (2014), Friedrichs e Rothe (2014), Molina e Whyte (2015) falam sobre o state-corporate crime e sobre questões jurídicas coercitivas, como forma de coibir o comportamento criminoso. Ademias, para eles, os state-corporate crime ocorrem com a condescendência do estado ou até mesmo partem dele. Corroborando a essa mesma linha de tratamento do tema dos crimes corporativos, que analisa as relações entre o mesmo e o estado, têm ainda os estudos de Leighton (2013), Finley (2012) que enfatiza o state-corporate crime ligado ao esporte em olimpíadas e copas do mundo, tais como processo de licitação, hospedagem, abuso de poder, entre outros.

Já outros como Bernal, Forero e Rivera (2014), Kambellari (2014), Pontell e Geis (2010) dão ênfase a regulamentações dos crimes corporativos cometidos em países específicos, como por exemplo, casos na Espanha, Albânia, China e Japão. Além desses, em uma perspectiva Marxista, Bittle (2015) ressalta a importância de transcender os esforços de reforma da lei do estado canadense.

Diante dos variados resultados das pesquisas sobre o tema, adotou-se neste trabalho a perspectiva de Medeiros (2013) sobre os crimes corporativos, pela autora adotar uma perspectiva sociológica do tema, que busca explorar o lado sombrio das organizações, bem como, no quanto o ambiente favorece a motivação para tais crimes. Não buscamos neste trabalho fazer considerações profundas no âmbito jurídico e sim, levantar reflexões sobre o papel da corporação na indução da ocorrência dos mesmos, uma vez que, pelos referenciais encontrados podemos concluir que as ênfases das pesquisas recentes são dadas ao papel do Estado como regulador e também às leis e punições, bem como as brechas encontradas nas mesmas.

Os estudos organizacionais tendem a ser realizados considerando o lado positivo das organizações, como ambientes favoráveis ao sucesso e tratam seu lado negativo com excepcionalidade. Conforme Medeiros (2013) o lado negativo das organizações, bem como o crime corporativo, erros e acidentes são acontecimentos que tendem a ser marginalizados e até excluídos das teorias que ao frisar prescrições ou descrições sobre o conceito de organizações e sobre sua forma de funcionamento, subestimam esse lado negativo não considerado como uma problemática central na área.

A autora ressalta a importância de estudos que denunciem esse lado, principalmente no que tange aos crimes corporativos, uma vez que, sua ocorrência tem sido enunciada com frequência graças às mudanças sociais, tecnológicas e a maior acessibilidade a informações (Medeiros, 2013). Diante disso é elucidada a necessidade de tratar dos crimes corporativos na área de estudos organizacionais, justificando que a ocorrência desses se dá na busca pelo alcance dos objetivos organizacionais.

As corporações mesmo orientadas para o atigimento de benefícios baseados em riscos são menos sucetíveis a ameaças e sanções da lei (Yeager, 2016) e os crimes corporativos tem se revelado como um assunto de grande interesse graças ao crescimento de sua ocorrencia na "América Corporativa", com consequencias danosas e alcances notáveis (Steffensmeieir, Schwartz \& Roche, 2013).

Tendo isso posto, Medeiros (2013) tentando descortinar a faceta negativa das organizações modernas e até mesmo evidenciar a necessidade da realização de estudos que demonstrem o lado sombrio das organizações, pela cultura do management ser caracterizada apenas por aspectos de racionalidade, sucesso e certezas, desenvolveu estudos organizacionais que se refere aos crimes corporativos. A referida autora não procura tratar especificamente as leis ou punições, o crime corporativo tal qual como estudado por ela se refere a um processo social, pertencente a estruturas sociais, que favorecem ou não a sua ocorrência, não cabendo julgamentos no que se refere a legislação brasileira, o que é reforçado no trecho:

[...] É preciso ir além das fronteiras desse campo para entender o modo pelo qual os crimes corporativos são produzidos, bem como as leis são construídas, interpretadas e aplicadas. Ainda, é preciso entender quais são as práticas criminosas geradas no contexto das corporações, ou melhor, como as variáveis que influenciam a dinâmica e a gestão organizacional são articuladas de modo que tais práticas ocorram. (MEDEIROS, 2013, pp. 75 - grifo nosso).

Sendo nas corporações o lugar onde esses crimes acontecem, Medeiros e Alcadipani (2013) relatam que a corporação é o modelo de organização preferida dos capitalistas graças à crescente interferência e poder que podem exercer em todas as áreas da sociedade, o que "Ihes permite escolher os recursos, as condições e a localização de suas operações de modo a obterem condições de produções vantajosas, ao mesmo tempo em que eliminam quaisquer tipos de limitações e restrições. " (Medeiros \& Alcadipani, 2013, p. 3).

As multinacionais assentam sua influência e poder na obtenção de concessões e para instalarem-se em ambientes de negócios que favoreçam a mão de obra qualificada a um custo baixo e também pela baixa regulamentação das condições trabalhistas e uma legislação frouxa. Assim, os indivíduos perdem seu poder na sociedade na medida em que as corporações estabelecem o seu domínio, guiando a sociedade na direção de seus interesses trazendo malefícios resultantes da má conduta e de desastres. (Silveira \& Medeiros, 2014). "A vida está ficando melhor para aqueles que expõem a injustiça, mas as empresas continuam a lutar para trás - muitas vezes contra seus próprios interesses" (The Economist, 2015. Tradução livre).

Levando em consideração esse poder que as corporações exercem de forma a disseminar comportamentos necessários ao alcance de seus objetivos, a autora critica estudos que tratam o crime corporativo de forma funcionalista e acrítica, pois, esses dão ênfase em antecedentes organizacionais, institucionais e 
individuais que desencadearam em crimes corporativos, sem considerar o pensamento de que as práticas criminosas são influenciadas na dinâmica da gestão organizacional e articuladas de tal forma que há a permissão para que elas ocorram. Ela argumenta ainda que, a introdução de estudos alternativos aos tradicionais, no que se referem aos crimes corporativos é lógica quando "a esses se associam as noções de emancipação da sociedade e de que a administração é um fenômeno político, cultural e ideológico" (Medeiros, 2013 p. 113).

Para fins de elucidação em suas pesquisas, ela considera como estudos precursores os que se destinam à concepção de White Collar Crime ${ }^{3}$. Através dos estudos de Sutherland (1940, 1941, 1949) são citados exemplos de White Collar Crimes como a manipulação de informações em relatórios financeiros, suborno, informações falsas em publicidade, desvio de fundos, relatando que muitos deles são cometidos por corporações. É esclarecido também que o White Collar Crime está inserido no contexto dos crimes corporativos, contudo, o segundo é mais abrangente que o primeiro, pois, o crime corporativo é cometido não só contra a organização, mas também em defesa dela, contra consumidores, ambiente, competidores, investidores e população em geral e como similaridade apresentam os seus custos que se comportam de forma maior do que em crimes comuns.

Medeiros e Alcadipani (2013) esclarecem ainda que os comportamentos criminosos nas corporações dificilmente recebem tal classificação - geralmente denominados como falhas, acidentes, tragédias ou fatalidades. Parte disso se deve ao fato das próprias corporações possuírem poder de influência sobre a elaboração e aplicação das leis, beneficiando cidadãos corporativos. "O país tem leis, mas essas leis tem brechas e é por entre elas que as corporações continuam a agir no país sem serem consideradas criminosas pela justiça" (Medeiros \& Alcadipani, 2013).

Além disso, é relatada a funcionalização do crime, quando o mesmo passa a ser considerado somente quando há condenação, e criticam o tratamento homogêneo dado às suas tipologias, uma vez que os crimes cometidos por pessoas de alto status econômico tem tratamento diferenciado em relação aos de classes inferiores. Concomitantemente, os indivíduos ou sociedades em que os crimes dos poderosos geralmente possuem a liberdade e rescursos significativos, muitas vezes utilizam-se da adjetivação de "criminoso" em relação aos outros ao mesmo tempo em que são capazes de resistir a tal adjetivação para si (Bernal, Forero \& Rivera, 2014).

Silveira e Medeiros (2014) fazem alusão à principal questão que norteia o crime corporativo no país, questão essa, referente aos motivos pelos quais eles acontecem e como eles se transformam em parte do cotidiano social. Para eles, as corporações ao promoverem diretrizes que norteiam a tomada de decisões orientadas para a eficiência, lucro, para os seus interesses produzem o motivo dos crimes corporativos.
As organizações idealizam um tipo de comportamento e o controlam e, as mesmas condicionam comportamentos imorais e são omissos aos mesmos. É relatado ainda que a decisão para o comportamento criminoso não é tomada pelo indivíduo. A má conduta é incentivada pelas empresas em seus processos, cultura e estrutura. A própria teoria organizacional motiva os gestores a escolherem condutas que beneficiem os interesses da empresa. As questões normativas do ambiente interno das organizações são previamente produzidas para o alcance das metas dessa mesma organização, - a gestão das corporações, as políticas empresarias que norteiam sempre para as medidas mais eficientes e com maior retorno para as organizações. Dessa maneira, a crítica a essas diretrizes não são próprias da dinâmica organizacional, sendo “... a conduta dos indivíduos incentivada pela estrutura de regras e planos que os tornam incapazes de criticar e prever as consequências dos seus atos." (Silveira \& Medeiros, 2014, p. 228).

Além disso, “... nas ocorrências de crimes corporativos, um sistema esvazia o pensamento dos seus membros e não os deixa vislumbrar o quão sério pode ser o erro, a má conduta e os desastres" (Silveira \& Medeiros, 2014, p. 229 grifo nosso). A ação deliberada às organizações torna passível o entendimento de que as ações de crime corporativo ocorrem no contexto dos processos e estrutura organizacionais, sendo possível evitar tais ações, porém, para isso adota-se custos em que as corporações não querem assumir, deslocando assim, esse custo para a sociedade em geral admitindo-se outras práticas, que pouco irão permitir a associação da palavra crime aos acontecimentos do ambiente empresarial. (Medeiros, 2013). Ademais, os gestores são sensíveis às ameaças de punição e à perda de seu prestígio e renda

"[...] a normalização do desvio é uma combinação de fatores institucional, organizacional e social, porém, os níveis institucional e organizacional são cruciais para a análise dos crimes corporativos, haja vista que, quando esses são normalizados as decisões e ações que o provocam não são vistas como algo errado pelos membros organizacionais e pela comunidade." (Medeiros, 2013, p. 80 - grifo nosso).

Nota-se em seus estudos (Medeiros, 2013; Medeiros \& Alcadipani, 2013; Silveira \& Medeiros 2014) e na definição de crime corporativo abordada pelos autores o contexto do ambiente que permitiu ou ainda estimulou a ocorrência do crime corporativo. É evidente a perspectiva adotada por eles no sentido de que os crimes corporativos ocorrem na necessidade de busca por resultados, lucro, pelos objetivos corporativos.

Outrossim, em face do contexto social em que o poder das corporações é exercido e de estudos relacionados ao tema de crime corporativo, que buscam desvelar as consequências negativas das corporações, considerando que as concepções precedentes sobre tais crimes ocultam as consequências sofridas por suas vítimas e por fim acabam contribuindo para que esses acontecimentos criminosos sejam entendidos como inevitáveis, acidentais e não evitáveis, é definido o conceito de crime corporativo numa abordagem sociológica:

[...] uma ação ou omissão ilegal ou socialmente prejudicial e danosa contra o indivíduo ou a sociedade, produzida na interação de atores envolvidos em estruturas organizacionais ou interorganizacionais na

criminosos por sua situação socioeconômica e por inspirar confiança e ter prestígio na sociedade em geral (Medeiros; 2013a apud. Sutherland, 1941).
${ }^{3} \mathrm{O}$ crime de colarinho branco é o crime cometido por indivíduos com grande respeitabilidade e status social em sua ocupação, caracterizando os 
busca de objetivos corporativos de uma ou mais corporação de negócios, resultando em prejuízos imateriais ou materiais aos seres vivos e às atividades humanas (Medeiros, 2013a, p. 59, grifo nosso).

De forma conjunta a atuação liberalizada das corporações é importante ressaltar também a perda da condição interventiva do Estado, que agora é apenas um regulador da ordem social. (Medeiros, 2013). Leighton (2013) defende que o estado está enfraquecido e que o papel do mesmo se limita a um zelar pela da ordem dos negócios e, na necessidade de comprovar sua legitimidade utiliza-se do combate ao crime nas ruas. Corroborando a esta ideia, Friedrichs e Rothe (2014) concebem que a maioria se não todos os crimes cometidos pelo Estado ou empresas, envolvem algum tipo de cooperação entre o Estado e corporação. Whyte (2014) acrescenta ainda que todos os casos de crime corporativo revelam algum elemento da direção estatal, aprovação tácita ou falha ao longo das linhas projetadas no âmbito criminal do estadocorporativo.

Finley (2013) ao citar Kramer, Michalowski e Kauzlarich (2002), relata o conluio entre o Estado e as corporações que resultam em morte, ferimentos, problemas de saúde, perdas financeiras, cada vez mais na economia capitalista globalizada a destruição cultural, tudo que está a ser isolado de todo o peso da criminalização para estas ações. Molina e Whyte (2015) afirmam em seus estudos que os crimes corporativos não surgem da incapacidade do estado de regular o poder corporativo e sim que o estado é permissivo com as condições para ocorrência dos crimes, são na verdade, "um regime abrangente de permissividade para um sistema de acumulação de capital, onde os estados garantem a reprodução da força do capital em sua forma corporativa. " (Molina \& Whyte, 2015, pp. 256 Tradução livre).

Dessa maneira, o poder e influência das corporações no estado e na sociedade "reflete na gestão das organizações que estimula manipulações contábeis, entre outras práticas ilegais e imorais com o objetivo de alcançar maiores lucros" e, nesse mesmo passo, "trabalhadores, consumidores e comunidades sofrem impactos de decisões corporativas na busca de objetivos empresariais, e os crimes corporativos se tornam cada vez mais comuns" (Medeiros \& Alcadipani, 2013, p. 3).

"[...] como as forças institucionais e organizacionais limitam as alternativas de escolha dos indivíduos, as normas e valores institucionalizados na sociedade, na indústria e na organização constituem-se em fatores causais para a ocorrência ou não dos crimes corporativos" (Medeiros, 2013, p. 79-80).

Concomitantemente a ação deliberada das corporações Medeiros (2013) ao se referir a Baucus e Dworkin (1991), afirma que as empresas que apresentam comportamento ilegal tem mais facilidade para convencer a opinião pública de que não fizeram nada errado, justificando suas ações ou afirmando que as leis e regulamentos apresentam ambiguidade. E, "a reação da população em relação às condutas é relevante para que se estabeleçam políticas públicas para a criminalização do crime corporativo." (Medeiros, 2013. p. 71).

[...] uma visão crítica de crime corporativo pode reconhecer que o crime como um processo social é moldado por aqueles que desfrutam de poder e influência político-econômica de forma a garantir que a denominação do que seja crime vá refletir sua visão de mundo e seus interesses, no caso das corporações, poder econômico, social e político. (Medeiros, 2013 p. 73)
Dessa forma, os crimes cometidos em nome da racionalidade se escondem atrás de uma suposta fatalidade e, ainda, são cometidos por seres humanos, contra seres humanos, em nome de uma corporação, cujo maior privilégio é justamente esse: não ser humano (Silveira \& Medeiros, 2014, p. 223).

Dessa forma, é passível a percepção de que os crimes corporativos estão suscetíveis de ocorrência nas corporações em qualquer operação que envolva o atingimento de seus objetivos $e$ que os mesmos são influenciados pela dinâmica interna nas organizações, ou seja, as condutas criminosas são favorecidas pelo conjunto de normas e cultura internas da organização e, essas condutas criminosas, os crimes corporativos são vistos como tais a partir do condicionamento de sua ocorrência a consequências mais ou menos sérias e aparentes aos olhos da sociedade. Ademais, no contexto social em que as corporações exercem seu poder e ainda receberem o apoio do Estado, muitas vezes até apoio na ocorrência de tais crimes é que os estudos organizacionais têm a necessidade de desvelar a dinâmica em que esses crimes acontecem, pois, esse desvelar pode se comportar como uma instigação à reflexão por parte dos gestores na adoção de práticas que levem ao comportamento criminoso.

Tendo isso posto, procura-se lançar luzes sobre o fato ocorrido do rompimento da barragem da mineradora Samarco e os Crimes Corporativos, como forma de chamar a atenção para o lado negativo, sombrio das organizações que internamente promovem um conjunto de regras para o alcance de seus objetivos que acabam por encorajar a ocorrência de comportamentos criminosos, qual sejam os crimes corporativos.

Para dar sequência a tal debate e enriquecimento da análise sobre o caso da barragem da Samarco, segue no próximo tópico o reconhecimento de diferentes crimes corporativos, o detalhamento sobre as suas vítimas e os seus verdadeiros custos.

\subsection{Os Tipos de Crime Corporativo, seus Custos e Consequências.}

Entendendo o crime corporativo segundo as definições de Medeiros (2013), sobre a ação em busca dos objetivos organizacionais, através de comportamentos criminosos estimulados pelas normas da corporação, admite-se que o crime corporativo pode ser uma ação consciente ou não, "bem como o agir negativo, a negligência, o não fazer aquilo que é devido" (Medeiros 2013, p. 60) desencadeando em prejuízos individuais ou sociais de forma ampla. Essas ações ou omissões se produzem em ambientes corporativos para alcançar objetivos empresariais trazendo resultados negativos como: "prejuízos sociais, físicos, financeiros, psicológicos, ecológicos, colocando a sociedade e - meio ambiente em condições de risco, dano ou perda" (Medeiros, 2013, p. 60 - grifo nosso). De acordo com Kambellari (2014) a violação de normas de segurança, ambiental e de trabalho, a evasão fiscal, bem como branqueamento de capitais provenientes de ações criminais estavam entre as primeiras violações que tiveram lugar no âmbito das empresas privadas e, acrescentando ainda, os crimes corporativos que são cometidos por indivíduos e administração incluem, mas, não são restritos a crimes relacionados com títulos, fraudes contra consumidores, fraudes 
fiscais, políticas, casos de corrupção, suborno e falência (Enofe, Ekpulu \& Ajala, 2015).

Tendo isso posto, entende-se que as vítimas dos crimes corporativos estão além da própria corporação e os atores envolvidos nos atos. Medeiros (2013) ao realizar seus estudos, utiliza as categorias Grabosky e Braithwaite (1987) sobre os crimes e suas vítimas. Os crimes corporativos são divididos em dez categorias: crimes corporativos econômicos; de tributação; de saúde e segurança ocupacional, de consumo; de práticas comerciais restritivas; de produção de alimentos; padrões de segurança; ofensas econômicas contra empregados e práticas discriminatórias, sendo em termos de citação, as mais relevantes para o presente trabalho as que se referem ao crime corporativo de saúde e segurança ocupacional, que se direcionam à condições inadequadas de trabalho com relação à segurança de equipamentos e instalações, à insalubridade e periculosidade e, os crimes corporativos ambientais que se referem a emissão de gases e poluentes; produção e manuseio de substancias perigosas e poluição sonora.

No que se refere às principais vítimas, encontram-se: o governo; as organizações; investidores e poupadores; consumidores; trabalhadores e por fim, o público. Dentre essas, as mais relevantes para análise neste artigo são os trabalhadores, vítimas de crimes corporativos com características de negligência quanto às regulamentações de saúde e segurança no trabalho e violação das leis trabalhistas vigentes e o público, vítimas de violações na legislação ambiental, emissões ilegais da indústria, poluição e contaminação do solo, água e rios e também a poluição sonora. Contudo, os autores relatam ainda que nem sempre as vítimas tem consciência dos prejuízos a que sofreram e que as perdas pessoais podem ser baixas quando os lucros obtidos com a prática criminosa são assaz elevados.

Medeiros (2013) ressaltam em sua pesquisa, que os custos do crime corporativo são inestimáveis, muito maiores do que os custos que incorrem sobre os crimes "comuns" e, os prejuízos sociais são superiores em relação aos prejuízos econômicos. Esses custos tem certa dificuldade em serem identificados "haja vista que em muitos desses crimes não são relatados os prejuízos reais para não constranger os negócios envolvidos" (Medeiros, 2013, p. 66). Entretanto, os autores recorrem a estudos como os de Payne (2012) e Freidrichs (2009), para se estabelecer relações entre os crimes corporativos e os custos a ele incorridos. Dentre os custos citados, podemos relacionar os custos de poluição ambiental; prejuízos físicos, doenças e mortes decorrentes de tais crimes; traumas psicológicos das vítimas levando a perdas emocionais referentes aos sentimentos provados pela sociedade ao serem expostos ao crime corporativo; a alienação do trabalho; as perdas econômicas individuais que se referem às perdas econômicas sofridas pelos indivíduos ou negócios; as perdas econômicas sociais decorrentes de custos de falências entre outros custos envolvidos neste processo. Além disso, a gravidade dos crimes corporativos e sua amplitude podem gerar impactos no valor da democracia e dos direitos humanos (Bernal et al., 2014).
Dessa forma, busca-se lançar reflexões que buscam compreender o tema de crime corporativo tendo como objeto de estudo o acontecimento do rompimento da barragem da mineradora Samarco, tendo em vista que os crimes corporativos cometidos contra empregados, consumidores, meio ambiente e a comunidade "constituem em categorias analíticas ricas para a compreensão da criminalidade corporativa em todos os seus aspectos, como os seus antecedentes e as suas consequências" (Medeiros, 2013, p. 64).

Além disso, Lasslett, Green e Stańczack (2014), ressaltam a importância de movimentos de resistência a práticas criminosas, particularmente às realizadas pelo Estado ou com apoio do mesmo, como uma forma de elucidar transformações emancipatórias, corroborando a esta ideia Medeiros:

[...] o papel desempenhado (ou desejável) pela sociedade, na pessoa de seus cidadãos, é questionar as práticas e condutas das corporações que afetam o modo de vida atual e futuro. As mudanças sociais requeridas para que os crimes corporativos sejam evitados, ou melhor, para que não tenhamos que arcar com os danos e prejuízos provocados por eles, que são lucrativos para as corporações, têm sua gênese no questionamento quanto à dominação das corporações na sociedade contemporânea, bem como suas responsabilidades diante da transgressão corporativa (Medeiros, 2013, p. 70)

Assim, destaca-se que os custos envolvidos nas consequências dos crimes corporativos são imensuráveis em valores monetários, uma vez que envolvem custos também humanos, psicológicos e sociais, o que dificulta muitas vezes a percepção dos danos pelas vítimas e neutralizando o comportamento criminoso, não deixando afluir a percepção do quão sério são esses acontecimentos e quais são os verdadeiros responsáveis que discutimos a seguir.

\section{A Lama da Samarco e o Crime Corporativo}

O presente artigo tem como proposta contribuir com reflexões do campo dos estudos organizacionais, ao lançar luzes sobre o tema de crime corporativo, tendo como objeto de estudo o caso da "Lama da Samarco", valendo-se da constatação de que os crimes corporativos são pouco abordados pela academia e, ao mesmo tempo, demonstram a necessidade de um conhecimento que revele não só os aspectos positivos do management, como também o seu lado sombrio. Como é destacado por Silveira e Medeiros (2014) o reconhecimento da existência de um lado sombrio nas organizações permite que os gestores passem a refletir sobre a necessidade de se empregar práticas transformadoras, ao passo que: "compreender os crimes corporativos, nessa concepção, é aceitar que eles estão a nossa volta, no cotidiano de nossas vidas, o que é bastante desconfortável para aqueles que tem uma visão unicamente otimista quanto a gestão" (Silveria \& Medeiros, 2014, p. 223).

Além disso, este trabalho consolida-se como uma reflexão necessária que desemboca em uma tomada de posição por parte da academia, uma vez que, como evidenciado por alguns estudiosos citados no corpo deste trabalho, o Estado perdeu grande parte de seu poder de regulamentação e legimidade diante do cenário capitalista, sendo ainda que a ocorrencia dos crimes corporativos pode ser considerada como advinda de um acordo de cooperação entre o Estado e as empresas e, além disso, a ocorrência do crime corporativo também é influenciada pela tomada 
de decisões dos gestores baseados em critérios e hábitos disseminados pela própria organização. Diante disso, acredita-se na capacidade de denúncia da área de estudos organizacionais demonstrando o lado sombrio das organizações, bem como o crime corporativo, uma vez que o poder público e os gestores não são alheios a esse fenomeno e, portanto, não apresentarão um comportamento crítico diante dos fatos ocorridos.

Além disso, é passível o entendimento da problemática em torno do "Lama da Samarco" e o crime corporativo, pela a mesma ter sofrido com a negligência de sua cúpula decisória, que adotou medidas de risco quando permitiu a continuidade das operações na barragem de Fundão em detrimento de práticas alternativas de uso da mesma, mas que não levavam à maior eficiência e maiores lucros à mineradora, características, essas, também ligadas ao crime corporativo, que ocorrem na busca por seus objetivos e que poderiam ser evitados a um preço que as corporações não estão dispostas a assumir. As perdas pessoais nesse caso foram subestimadas em relação à capacidade lucrativa da mineradora em continuar operando com uma barragem em condições precárias.

Podemos ressaltar ainda, a identificação do acontecimento com os crimes corporativos que se referem a negligencias de saúde e segurança no ambiente de trabalho e também os crimes corporativos ambientais referentes à contaminação da água, do solo e rios. Os vários prejuízos sofridos por seus trabalhadores, comunidade e público em geral, dentre eles os prejuízos econômicos pela paralisação das operações da empresa, a baixa arrecadação tributária na cidade e o resfriamento das trocas comerciais e do consumo da região, a paralisação de atividades de subsistência de dependiam dos ecossistemas atingidos, além das perdas materiais dos moradores das regiões atingidas; os prejuízos físicos devido a mortes e doenças agravadas com a ocorrência do rompimento; os prejuízos psicológicos sofridos pelas vítimas que perderam familiares, bens materiais, suas identidades e referências culturais que não são substituídas por medidas paliativas após o ocorrido.

É possível relacionar com o crime corporativo também, a tentativa da organização de neutralizar o seu papel no rompimento alegando que o mesmo se deu como um "acidente", "desastre", como se o rompimento tenha acontecido devido a fatores incontroláveis ou não previsíveis por eles e ainda, que a empresa estava em conformidade com as exigências ambientais e de operação da barragem, omitindo a consciência dos riscos a em que a população estava incorrida, tentando ao mesmo tempo, convencer a opinião pública de que suas condutas não foram intencionais e que o risco era desconhecido. Ademais, a tentativa de mudar os responsáveis pelo inquérito também se relacionar com o poder das corporações sobre as leis e suas brechas, também características da ocorrência do crime corporativo.

Podemos ainda questionar neste caso o papel do Estado como regulador e na apuração dos fatos. A corporação em questão agiu de forma deliberada em relação à situação segura de sua barragem e consequentemente de suas operações, contudo, as fiscalizações antes do rompimento apresentaram falhas de forma clara. A descoberta de que a empresa fraudou documentos sobre as condições da barragem e ainda sobre a quantidade de rejeitos que nela eram despejados poderia ter sido feita antes de acontecer o rompimento, isso se o Estado cumprisse o seu papel de regulador e de procurar o bem-estar social.

Por fim, entende-se que a partir do construto de Crimes Corporativos proposto por Medeiros (2013) de que eles são produzidos por atores organizacionais na busca por objetivos organizacionais, produzindo prejuízos materiais e imateriais, podemos aproximar o rompimento da barragem com um crime corporativo, pois, a continuação das operações da empresa com uma barragem irregular, assumindo o risco do rompimento para continuar alcançando os objetivos da empresa foi uma decisão tomada por seus atores organizacionais e, esses mesmos atores foram indiciados e respondem por terem assumido esse risco, o que ocasionou em um crime corporativo - cujas responsabilidades ainda estão sendo apuradas - com consequências materiais e imateriais, que vão desde perdas humanas, ambientais, traumas, prejuízos psicológicos e bens materiais.

Além disso, a condenação da empresa pelos órgãos ambientais ao pagamento de multas por degradação ao meio ambiente, indiferentemente da intenção, mas por assumir o risco, já nos permite a consumação da ideia de que o crime ambiental foi consolidado e que medidas de reparação devem ser tomadas.

\section{Considerações Finais}

Diante do exposto sobre o caso da "Lama da Samarco" e os Crimes Corporativos, mesmo que este trabalho não seja de ênfase jurídica, não podemos consolidar a empresa como criminosa enquanto o processo não se concretizar como "coisa julgada". Porém, o que se pode afirmar é que o crime corporativo ocorreu. Logo, considera-se então que a classificação do evento da "Lama da Samarco" como crime corporativo é validada e que as hipóteses e aproximações lançadas entre o crime corporativo e o vento da lama podem ser consideradas, mas, ainda existem demais variáveis a serem consideradas neste caso para a consolidação da afirmação sobre culpabilidade da empresa.

O que de fato afirmamos é que a face obscura das ações da Samarco que favoreceram o processo do rompimento deve ser levada em conta e não somente a ação individual de seus agentes, pois, punir os mesmos como únicos responsáveis, sem vislumbrar os antecedentes criminais da empresa intrínsecos neste processo, é acabar por neutralizar a gravidade do fato ocorrido e consolidar ainda mais o poder e liberdade de ação das corporações na sociedade.

Diante disso, podemos constatar a ocorrência do crime, bem como as suas aproximações às categorias de crimes corporativos, uma vez que as informações divulgadas sobre o caso e ainda as palavras proferidas por agentes jurídicos, que afirmam sobre o conhecimento prévio da empresa sobre os riscos de rompimento, a tentativa de tomar medidas paliativas e oculta-las após rompimento e ainda a fraude nos documentos no que se refere à quantidade de rejeitos recebida na barragem que se rompeu. Além disso, as consequências e perdas com os crimes corporativos são assaz comuns com as que foram geradas após o rompimento, tratando- 
se tanto de consequências e perdas materiais, quanto imateriais, principalmente no que se refere à sociedade e meio ambiente.

Além disso, procurou-se estabelecer reflexões acerca das relações do crime corporativo com tal acontecimento, bem como, trazer a problemática principal de tais crimes para pesquisas futuras. Denuncia-se ainda a necessidade da realização de pesquisas que norteiam o tema de crimes corporativos, como forma de desvelar também o lado sombrio das organizações e não somente os aspectos positivos da gestão corporativa. Nota-se ainda certa urgência nesse tratamento, uma vez que a atualidade do evento da "Lama" demonstra a possibilidade de adoção de práticas sombrias na atualidade e, em contrapartida, pesquisas que se debrucem sobre os aspectos negativos do management são pouco abordadas. Ademais, evidenciamos o papel de estudantes acadêmicos da área em desvelar esse lado sombrio das organizações, uma vez que há dúvidas quanto às relações da empresa e o Estado, sendo este o principal responsável pela prevalência dos interesses dos indivíduos da sociedade.

Buscamos com este artigo uma aproximação inicial sobre o tema do crime corporativo e o caso da queda da barragem de Fundão, ocorrido em novembro de 2015. Muitas investigações ainda precisam ser realizadas, tanto no âmbito acadêmico, quanto legal, para que sejam apurados devidamente os fatos que levaram à queda da barragem, bem como suas consequências para a sociedade e para o meio ambiente.

Destarte, mesmo sendo uma aproximação inicial, nos valemos da prerrogativa de tratarmos um tema tão árido na esfera da gestão, dada sua importância e urgência. Ressaltamos a necessidade de enxergarmos os crimes corporativos como um problema real que vai além das características individuais e antecedentes dos atores que comentem tal comportamento. Levantamos ainda a necessidade do caso do rompimento da barragem da Samarco ser encarado também como um problema do management e uma realidade interna das organizações industriais modernas, trazendo a percepção de que os crimes corporativos são, antes de serem transformados em comportamento criminoso, influenciados pelas próprias corporações.

Por fim, acreditamos que nosso texto contribuirá para a trilha dos estudos organizacionais críticos e o desvelamento dos impactos nocivos da forma unidimensional da gestão no capitalismo moderno e seus custos diretos e indiretos a sociedade. Um primeiro e importante passo foi dado, resta-nos fazer cumprir os objetivos da pesquisa crítica, qual seja, criar meios para o esclarecimento, em busca de formas mais justas e igualitárias de gestão.

\section{Referências}

Agência Minas, (2016) Indiciamentos. Disponível em: <http://www.agenciaminas.mg.gov.br/ckeditor assets/attachments/806/indici amentos.pdf> Acesso em: 04 Abr. 2018.

Associação de Combate aos PoluenteS - ACPO (2012). Rodhia Cubatão: Quarenta e Sete Anos Poluindo e Envenenando Ecossistemas e Pessoas. Disponível em: <http://www.acpo.org.br/tac/resumo_historico_rhodia.pdf> Acesso em: 04 Abr. 2018.

Bardin, L. (2002) Análise de conteúdo. Lisboa: Edições 70, Lda, 2002. 229p. BBC Brasil, 10 de novembro de 2015. Desastre em Mariana: 5 perguntas sem resposta sobre o rompimento da barragem. Disponível em: <http://www.bbc.com/portuguese/noticias/2015/11/151106_minasgerais_per guntas_hb>Acesso em: 26 Mai. 2017
Belchior, G. P. N., \& Primo, D. A. S. A responsabilidade civil por dano ambiental e o caso Samarco: desafios à luz do paradigma da sociedade de risco e da complexidade ambiental. RJurFA7, Fortaleza, v. 13, n. 1, p. 10-30 jan./jun. $2016 . \quad$ Disponível em: <http://www.egov.ufsc.br/portal/sites/default/files/a_responsabilidade_civil_p or_dano_ambiental_e_o_caso_samarco_desafios_a_luz_do_paradigma_da sociedade_de_risco_e_da_complexidade_ambiental.pdf $>$ Acesso em: 25 Fev. 2017.

Bernal, C., Foreto, A., and Rivera, I. State-corporate crime and social harm in the Spanish crisis. State Crime Journal 3.2 (2014): 220+. Academic OneFile. Disponível em: <http://gogalegroup.ez28. periodicos.capes.gov.br/ps/i.do?id=GALE\%7CA403918838\& $v=2.1 \& u=$ capes\&it=r\&p=AONE\&sw=w\&asid=9ca3aa7a31 feb25377af7bb6f0 9134e6> Acesso em: 26 Mai. 2017

Bittle, S. Beyond Corporate Fundamentalism: A Marxian Class Analysis of Corporate Crime Law Reform. Critical Sociology 2015, Vol. 41(1) 133151.

Brasil Mineral, 22 de Setembro de 2016 (2016) Vazamento de cianeto em usina argentina. Disponível em argentina> Acesso em: 04 Abr. 2018.

Calixto, B. 10 de novembro de 2015 (2015). Estes são alguns dos danos ambientais causados pela lama da barragem da Samarco. REVISTA EPOCA. Disponível em: <http://epoca.globo.com/colunas-e-blogs/blog-doplaneta/noticia/2015/11/estes-sao-alguns-dos-danos-ambientais-causadospela-lama-da-barragem-da-samarco.html> Acesso em: 26 Mai. 2017

Carneiro; J. D. 05 de maio de 2016 (2016). Seis Meses Após Lama da Samarco, Solidão Assombra Ultimos Moradores do Volarejo de Minas. BBC BRASIL. Disponível em: <http://www.bbc.com/portuguese/brasil/2016/05/160505 lama samarco soli dao_jc_if>Acesso em: 26 Mai. 2017

Ceraque, E; Mena, F. 15 de novembro de 2015 (2015). Tragédia em Minas Gerais deve secar rios e criar 'deserto de lama'. Folha de São Paulo. Disponível em: <http://m.folha.uol.com.br/cotidiano/2015/11/1706510 tragedia-em-minas-gerais-deve-secar-rios-e-criar-deserto-delama.shtml?mobile> Acesso em: 26 Mai. 2017

Coutinho, I; E; C., Avzaradel, P; C; S., \& Farias, T; Q. (2015) Conclusões do GT1 - CETEM - desastre de Mariana/MG. Disponível em: <http://www.ufff.br/poemas/files/2015/12/CETEM-GT1-FINAL.pdf> Acesso em: 02 Jun. 2017.

Correio do Brasil, 20 de Julho de 2011 (2011). Greenpeace revela que atividades da mineradora Barrick Gold afetaram geleiras. Disponível em: <http://www.correiodobrasil.com.br/greenpeace-revela-que-atividades-damineradora-barrick-gold-afetaram-geleiras/> Acesso em: 04 Abr. 2018. Diário de Pernambuco, 30 de Março de 2017 (2017) Atividade em mina argentina de Barrick é suspensa após rompimento de duto. Disponível em:

<http://www.diariodepernambuco.com.br/app/noticia/politica/2017/03/30/inter na_politica,696790/atividade-em-mina-argentina-de-barrick-e-suspensaapos-rompimento-de-d.shtml> Acesso em: 04 Abr. 2018.

Diniz, M., 18 de Agosto de 2016 (2016). Justiça Manteve Condenação da Samarco a Pagar Recuperação do Rio Doce, diz Vale. Agência Brasil. 18 de Agosto de 2016. Disponível em: http://agenciabrasil.ebc.com.br/geral/noticia/2016-08/justica-mantemdecisao-que-condena-samarco-pagar-recuperacao-do-rio-doce> Acesso em: 26 Fev. 2017.

El País. 22 de Setembro de 2016 (2016) El gobierno argentino denuncia a Barrick Gold por verter cianuro.

Disponível em

$<$ http://internacional.elpais.com/internacional/2016/09/22/argentina/1474555 750_266082.html> Acesso em: 04 Abr. 2018.

Enofe, A.O., Ekpulu, G.A., and Ajala, T.O. Forensic accounting and corporate crime mitigation. European Scientific Journal. 7 (Mar. 1, 2015): p167. Disponível em: <http://gogalegroup.ez28. periodicos.capes.gov.br/ps/i.do?id=GALE\%7CA410903556\& $v=2.1 \& u=$ capes $\& i t=r \& p=A O N E \& s w=w \& a s i d=7794530 f c d b 0943 a d 34 c 77 f 003$ f4922e > Acesso em: 6 Jun. 2017.

Estado de Minas, 22 de Março de 2016 (2016). STJ suspende investigações de desastre em Mariana. Disponível em: http://www.em.com.br/app/noticia/gerais/2016/03/22/interna_gerais,746311/s tj-suspende-investigacoes-de-desastre-em-mariana.shtml Acesso em: 06 Jun. 2017.

Exame. 22 de Setembro de 2016 (2016) Argentina denuncia mineradora Barrick Gold por Vazamento. Disponível em: <http://exame.abril.com.br/negocios/argentina-denuncia-mineradora-barrickgold-por-vazamento-em-mina-de-ouro/> Acesso em: 08 Jun. 2017.

Fernandez, A; M, 07 de Dezembro de 2015 (2015). Megamineração: não são acidentes. Le Monde Diplomatique Brasil. Disponível em: $<$ http://diplomatique.org.br/megamineracao-nao-sao-acidentes/> Acesso em: 04 Abr. 2018.

Finley, L. L. (2013) Examining state and state-corporate crime surrounding major sporting events. Contemporary Justice Review. 16, 2 , 228-250, June 2013. ISSN: 10282580.

Frazão, A. 28 de novembro de 2015 (2015). Empilhadas em hotéis, as vítimas da lama da Samarco tentam retomar a vida. DCM. Disponível em: 
<http://www.diariodocentrodomundo.com.br/empilhadas-em-hoteis-asvitimas-da-lama-da-samarco-tentam-retomar-a-vida-por-aline-frazao/> Acesso em: 25 Mai. 2017

Friedrichs, D. O, and Rothe, D. L. (2014) State-corporate crime and major financial institutions: interrogating an absence. State Crime Journal 3.2 (2014): 146+?. Academic OneFile. Disponível em: <http://gogalegroup.ez28. periodicos.capes.gov.br/ps/i.do?id=GALE\%7CA403918834\& $v=2.1 \& u=$ capes $\& i t=r \& p=A O N E \& s w=w \& a s i d=9 f 80 e 33 f 1768 \mathrm{fc} 1679035 \mathrm{fb} 64 \mathrm{fc}$ da8ac> Acesso em: 01 Jun. 2017.

G1 MG. 05 de Novembro de 2015 (2015a). Barragem se rompe, e enxurrada de lama destrói distrito de Mariana. Disponível em: <http://g1.globo.com/minas-gerais/noticia/2015/11/barragem-de-rejeitos-serompe-em-distrito-de-mariana.html> Acesso em: 29 Mai. de 2017.

G1 MG. 06 de Novembro de 2015 (2015b). USP registrou tremores em Minas antes do rompimento de barragens. Disponível em: <http://g1.globo.com/minas-gerais/noticia/2015/11/usp-registrou-tremoresem-minas-antes-de-rompimento-de-barragens.html> Acesso em: 29 Mai. 2017.

G1 MG. 21 de Novembro de 2015 (2015c). Moradores pedem que Samarco fique em Mariana mesmo após desastre. Disponível em: $<\mathrm{http}: / / \mathrm{g} 1$.globo.com/minas-gerais/desastre-ambiental-em-

mariana/noticia/2015/11/moradores-pedem-que-samarco-fique-em-marianamesmo-apos-desastre.html> Acesso em: 29 Mai. de 2017.

G1 MG. 05 de Dezembro de 2015 (2015d). Rompimento de barragem da Samarco, em Mariana, completa um mês. 05 Dez. 2015d. Disponível em: <http://especiais.g1.globo.com/minas-gerais/2015/desastre-ambiental-emmariana/1-mes-em-numeros/> Acesso em: 07 Jun. 2017

G1 MG. 01 Março de 2016 (2016a). MP faz novo pedido para processo de Mariana ir à Justiça Federal. Disponível em: <http://g1.globo.com/minasgerais/desastre-ambiental-em-mariana/noticia/2016/03/mp-faz-novo-pedidopara-processo-de-mariana-ir-justica-federal.html> Acesso em 27 de Mai de 2017.

G1 MG. 03 de Março de 2016 (2016b). Samarco quer voltar a operar ainda em 2016, diz presidente. Disponível em: <http://g1.globo.com/espiritosanto/desastre-ambiental-no-rio-doce/noticia/2016/03/samarco-quer-voltaroperar-ainda-em-2016-diz-presidente.html> Acesso em: 27 Mai. 2017.

Gil, A. C. Métodos e técnicas de pesquisa social. 3. ed. São Paulo: Atlas, 1991. 207 p.

Greenpeace; 20 de Abril de 2015 (2015). Desastre no Golfo do México Completa Cinco Anos. Disponível em completa-cinco-anos/> Acesso em: 25 Mai. 2017.

Greenpeace; Julho de 2011 (2011). Barrick: Minería Responsable de Destruir los Glaciares. Julho, 2011. Disponível em: <http://www.greenpeace.org/argentina/Global/argentina/report/2011/cambio climatico/barrick_mineria_responsable.pdf> Acesso em: 07 Jun. 2017 Instituto Brasileiro do Meio Ambiente e dos Recursos Naturais Renováveis IBAMA (2015). Laudo Técnico Preliminar: Impactos ambientais decorrentes do desastre envolvendo o rompimento da barragem de Fundão, em Mariana, Minas Gerais. Brasília; 26 de novembro de 2015. Disponível em: <http://www.ibama.gov.br/phocadownload/noticias_ambientais/laudo_tecnico preliminar.pdf> Acesso em: 25 Mai. 2017

Jornal da Band. 09 de Junho de 2016 (2016). PF termina investigação sobre Mariana. Disponível em: <http://noticias.band.uol.com.br/cidades/noticia/100000809987/pf-terminainvestigacao-sobre-mariana.html> Acesso em: 26 Mai. 2017

Jornal Nacional. 25 de março de 2016 (2016). Lama da Samarco no Fundo do Mar Muda Vida Marinha na Foz do Rio Doce. Disponível em: <http://g1.globo.com/jornal-nacional/noticia/2016/03/lama-da-samarco-nofundo-do-mar-muda-vida-marinha-na-foz-do-rio-doce.html> Acesso em: 10 Jun. 2016.

Jornal Ponto Final. 12 de Fevereiro de 2016 (2016). Promotor Guilherme Meneghin afirma que troca de jurisdição é favorável a Samarco. Disponível em: <http://jornalpontofinalonline.com.br/noticia/5295/promotorguilherme-meneghin-afirma-que-troca-de-jurisdicao-e-favoravel-a-samarco> Acesso em: 07 Jun. 2017

Kambellari, E. (2014). Corporate Crime in Albania: Building the Path to Face a New Form of Criminality. European Journal on Criminal Policy and Research [0928-1371] Kambellari, Evisa yr:2014 vol:20 iss:2 pg:191 -204

Lampião. (2016). Do Fim ao Recomeço: quando a lama de uma barragem faz o tempo parar e o futuro persiste. Jornal - Laboratório do Curso de Jornalismo - UFOP. Edição № 21. Janeiro 2016. Fechado em 18 de Dezembro de 2015

Lasslett, K., Green, P., and Stańczak D. (2015) The barbarism of indifference: Sabotage, resistance and state-corporate crime. Theoretical Criminology November 2015 vol. 19 no. 4. pp. 514-533

Leighton, P. (2013). Corporate Crime and the Corporate Agenda for Crime Control: Disappearing Awareness of Corporate Crime and Increasing Abuses of Power. Western Criminology Review 14(2):38-51. Disponível em: <http://wcr.sonoma.edu/v14n2/Leighton.pdf> Acesso em: 02 Jun. 2017.

Medeiros, C. R. O., \& Alcadipani, R. (2013) Crimes Corporativos Contra a Vida e Necrocorporações. XXXVII Encontro da ANPAD. Anais. 2013. Disponível

<http://www.anpad.org.br/admin/pdf/2013 EnANPAD EOR908.pdf> Acesso em: 27 Mai. 2017
Medeiros, C. R. O., (2013). Crimes Corporativos Contra a Vida e Necrocorporações. Tese (Doutorado em Administração) - Escola de Administração de Empresas. Fundação Getúlio Vargas. São Paulo, SP, Brasil. Mello, O. (1995). Dossiê Caso "Rodhia". Disponível em: <http://www.acpo.org.br/biblioteca/bb/Dossie1.htm> Acesso em: $04 \mathrm{Abr}$ 2018

Governo do Estado de MG (2016). Secretaria de Estado de Desenvolvimento Regional, Política Urbana e Gestão Metropolitana. Relatório: Avaliação dos efeitos e desdobramentos do rompimento da Barragem de Fundão em Mariana-MG. Minas Gerais: Força Tarefa, 2016. 287p. Disponível em <http://www.agenciaminas.mg.gov.br/ckeditor_assets/attachments/770/relato rio_final_ft_03_02_2016_15h5min.pdf >. Acesso em: 01 Jun. 2017

Ministério Público Federal - MPF (2016). Procuradoria da República nos Estados de Minas Gerais e Espírito Santo - Força Tarefa Rio Doce. DENÚNCIA. 2016. Disponível em: <http://www.mpf.mp.br/mg/sala-deimprensa/docs/denuncia-samarco> Acesso em: 01 Jun. 2017.

Ministério Público Federal - MPF. 19 de Janeiro de 2017 (2017). MPF firma acordo preliminar com Samarco, Vale e BHP Billiton no valor de R\$ 2,2 bilhões. 2017. Disponível em: <http://www.mpf.mp.br/mg/sala-deimprensa/noticias-mg/mpf-firma-acordo-preliminar-com-samarco-vale-e-bhpbilliton-no-valor-de-r-2-2-bilhoes> Acesso em: 04 Abr. 2018

Molina, I. B., and Whyte, D. (2015) Entendiendo Los Orígenes Del Crimen Estatal-corporativo. Un Análisis de Los Desastres Del Prestige y Morecambe Bay. Revista Crítica Penal y Poder, Observatorio del Sistema Penal y los Derechos Humanos, Universidad de Barcelona, no 9, (pp.255278), Set. $2015 . \quad 2 \quad$ Disponível $\quad$ em: <http://revistes.ub.edu/index.php/CriticaPenalPoder/article/view/12035/1762 4> Acesso em: 08 Jun. 2017.

O Estadão. 01 de Março de 2016 (2016) Para não pagar multa, Samarco alega que rompimento de barragens não foi intencional. Disponível em: <http://zh.clicrbs.com.br/rs/noticias/noticia/2016/03/para-nao-pagar-multasamarco-alega-que-rompimento-de-barragens-nao-foi-intencional4987174.html> Acesso em: 04 Abr. 2018

O Globo. 20 de Abril de 2011 (2011). Vazamento da BP no Golfo do México Completa Um Ano. Disponível em: mexico-completa-um-ano-2793457> Acesso em: 04 Abr. 2018.

O Tempo. 25 de novembro de 2015 (2015). Lama da Barragem da Samarco já alcançou $826 \mathrm{~km}$ de extensão. Disponível em: <http://www.otempo.com.br/cidades/lama-da-barragem-da-samarcoj\%C3\%A1-alcan\%C3\%A7ou-826-km-de-extens\%C3\%A3o-1.1177963> Acesso em: 08 Jun. 2017.

Parreiras, M. 01 de Maio de 2016 (2016). Seis Meses Depois da Tragédia, Lama Ainda Ameaça e Deve Ser Contida Antes de Outubro. Estado de Minas. Disponível em: Acesso em: 08 Jun. 2017.

PoEMAS. (2015). Antes fosse mais leve a carga: avaliação dos aspectos econômicos, políticos e sociais do desastre da Samarco/Vale/BHP em Mariana (MG). Mimeo 2015 Disponível em: <http://www.cetem.gov.br/images/palestras/2015/mariana/poemas-

2015.pdf.> Acesso em: 02 Jun. 2017.

Pontell, H. N., and Geis, G. (2010). Introduction: White-Collar and Corporate Crime in Asia. Asian Journal of Criminology, Volume 5, Issue 2, pp 83-88, Dez. 2010. Disponível em <http://link.springer.com/article/10.1007\%2Fs11417-010-9093-4> Acesso em: 04 Abr. 2018.

Samarco, (2015). Fazer o que Deve ser feito: esse é o nosso compromisso. Disponível em: <http://www.samarco.com/wpcontent/uploads/2015/12/DossieSamarco_09_152.pdf>Acesso em: 03 Abr. de 2018.

Santana, R. L. S.; Moreira, C. T. C. (2016). Responsabilização empresarial por danos ambientais: o caso da joint venture Samarco. In: Âmbito Jurídico, Rio Grande, XIX, n. 150, jul 2016. Disponível em: <http://ambitojuridico.com.br/site/?n_link=revista_artigos_leitura\&artigo_id=17412>. Acesso em: 08 Jun. de 2017.

Silveira, R. A., \& Medeiros, C. R. O. (2014). Viver e morrer pelo trabalho: uma análise da banalidade do mal nos crimes corporativos. Organ. Soc., Salvador, v 21, n 69, p. 217-234 Disponível em <http://www.scielo.br/scielo.php?script=sci arttext\&pid=S1984-

92302014000200002\&Ing=en\&nrm=iso >. Acesso em: 08 Jun. de 2017

Steffensmeieir, D. J., Schwartz, J., and Roche, M. (2013). Gender and Twenty-First-Century Corporate Crime: Female Involvement and the Gender Gap in Enron-Era Corporate Frauds. American Sociological Review June 2013 vol. 78 n. 3. pp. 448-476.

TAE; Revista Técnica do Tratamento de Água e Afluentes. (2011). Mineração congela o mapa das geleiras. Disponível em: em: 07 Jun. 2017.

The Economist. 05 December 2015. (2015). The age of the whistleblower; Corporate crime.: 63(US). Academic OneFile. Disponível em: $<$ http://go.galegroup.com/ps/i.do?id=GALE\%7CA450209461\&v=2.1\&u=cape $s \& i t=r \& p=A O N E \& s w=w \& a s i d=1 d 34 a 316217716 f 965 f e 8412 d 327 c 478>$ Acesso em: 6 Jun. 2017

Universidade Federal do Espírito Santo - UFES (2016). Departamento de Oceanografia e Ecologia. Resultados Parciais das Análises Realizadas em Amostras Coletadas na Plataforma Adjacente a Foz do Rio Doce. 
Embarque NOc. Vital de Oliveira. 17p. Disponível em: <http://redeufesriodoce.ufes.br/sites/redeufesriodoce.ufes.br/files/field/anexo/Relatorio\%20P arcial\%20Expedi\%C3\%A7\%C3\%A30\%20NOc\%20Vital\%20de\%20Oliveira\% 20UFES\%20Fev\%202016\%20\%20final.pdf>. Acesso em: 03 Abr. 2018.

Uol. 26 de Fevereiro de 2016 (2016a). Samarco Quer Voltar a Operar em Mariana. Disponível em: <http://noticias.uol.com.br/ultimas-noticias/agenciaestado/2016/02/26/samarco-quer-voltar-a-operar-em-mariana.htm> Acesso em: 04 Abr. 2018.

Uol. 29 de Fevereiro de 2016 (2016b). Acordo coletivo prevê participação de atingidos por barragem em MG e ES. Disponível em: < http://noticias.uol.com.br/cotidiano/ultimas-noticias/2016/02/29/acordocoletivo-preve-participacao-de-atingidos-por-barragem-em-mg-e-es.htm> Acesso em 04 Abr. 2018.

Valor Economico. 25 de Fevereiro de 2016 (2016).Polícia pede prisão preventiva de ex-presidente da Samarco e mais 6 por tragédia. Disponíve em: <http://www.valor.com.br/empresas/4450942/policia-pede-prisao-de-expresidente-da-samarco-e-mais-6-por-tragedia> Acesso em: 03 Abr 2018.

Veja.com. 04 de Abril de 2016 (2016). BP Pagará US\$ 21 Bi Por Vazamento

no Golfo do México em 2010. Disponível em:

<http://veja abril com br/economia/bp-pagara-us-21-bi-por-vazamento-nogolfo-do-mexico-em-2010/> Acesso em: 04 Abr. de 2018.

Vergara, S. C. (2004). Projetos e relatórios de pesquisa em Administração. São Paulo: Atlas.

Vertices Inconfidentes 25 de Março de 2016 (2016). Abaixo-assinado reúne $9 \mathrm{mil}$ assinaturas pela volta da Samarco em Mariana. Disponível em: $<$ http://verticesinconfidentes.com.br/abaixo-assinado-reune-9-milassinaturas-pela-volta-da-samarco-em-mariana/1714.> Acesso em: $04 \mathrm{Abr}$ 2018

Whyte, D. (2014). Regimes of permission and state-corporate crime.State Crime Journal3.2 (2014): 237+. Academic OneFile. Disponível em: <http://gogalegroup.ez28. periodicos.capes.gov.br/ps/i.do?id=GALE\%7CA403918839\& $v=2.1 \& u=$ capes\& $i t=r \& p=A O N E \& s w=w \& a s i d=409 b 3 d 30 f a 779 b a 0 b 97 b 2889 a$ 410aac0 > Acesso em: 04 Abr. 2018.

Yeager, P. C. (2016). The Elusive Deterrence of Corporate Crime. Criminology \& Public Policy, Vol.15(2), pp.439-451. 